UDC 811,111

DOI https://doi.org/10.32838/2663-6069/2020.4-2/23

Mykhaylenko $V . V$.

King Danylo University

\title{
ON DYNAMICS OF THE LEXICAL MEANING
}

The article is focused on an attempt to distinguish between the lexical meaning of the unit "architecture" and its contextual meaning thatmakes it possible to determine the shift of the components in the lexical meaning which can serve as a trigger to form a new domain and reveal the relationship of subsystems in the language conceptual system. The word "architecture" actualizes the dominant component of "art" related to the semantic domain of "architecture". The word is usually embedded into various combinations in the sentence and it actualizes its components due to the lexicalgrammatical and lexical-semantic combinability. The modifiers of the headword "architecture" may actualize its either dominant or periphery semantic components. This makes the hypothesis of semantic shifts in the lexical meaning of the unit evident. In accordance with the dynamic semantics the noun architecture "the art of building, tasteful application of scientific and traditional rules of good construction to the materials at hand", developed from the borrowing in Middle French architecture (1560's), and earlier from Latin architecture, from architectus "master builder, chief workman" (see architect). Since that time the word architecture has realized 7 components: (1) the art of planning, designing; (2) constructing buildings; (3) the style in which a building is designed and constructed; (4) the architecture of the city's buildings. (5) the science, art, or profession of designing and constructing buildings, bridges (6) the internal organization of a computer's components we particular reference to the way in which data is transmitted; (7) the arrangement of the various devices in a complete computer system or network. This expansion of the lexical semantics of the word "architecture" is due to its combinability with other units of the sentence and discourse.

Key words: semantics, lexical, contextual, dynamic, domain, concept, shift, discourse.

Preamble. The end-goal of our paper is to distinguish between the lexical meaning of the unit architecture and its contextual meaning that makes it possible to determine the shift of the components in the lexical meaning which can serve as a trigger to form a new domain and reveal the relationship of subsystems in the language conceptual system. The noun architecture actualizes its dominant component of "art" related to the semantic domain of architecture. As the word is usually embedded into various combinations in the sentence it begins to correlate with them and actualize its components due to the lexical-grammatical and lexical-semantic combinability. The modifiers of the headword architecture may activate its either dominant or periphery semantic components. This makes the hypothesis of semantic shifts in the lexical meaning of the unit evident. When a periphery component ousts the dominant one there occurs a transition of the unit to another semantic domain.

Discussion. In philosophy the conceptual analysis is still ubi qutois and undergoing a revival. But it is also used in accounting for such phenomena as categorization, meaning change and linguistic understanding [6, p. 25]. The term conceptual analysis, according to Kipper, is used in two senses: (i) to denote the process of analysing concepts and (ii) it considers the intended results of such analysis [5, p. 9]. In my opinion, this analysis is complementary in investigating the word lexical meaning of the language-in-use. It is efficient in categorizing our worldview to represent it as a unity. A worldview is a mental model of reality - a framework of ideas and attitudes about the world, ourselves, and life, a comprehensive system of beliefs [11, p. 75].

Linguistic semantics studies the compositionality aspect of the word and is more concerned with literal meaning [2, p. 288; 13, p. 342]. We shall distinguish between several types of linguistic semantics.

In accordance with the dynamic semantics the noun architecture "the art of building, tasteful application of scientific and traditional rules of good construction" developed from the Middle French loan architecture (1560's), and earlier from Latin architectura, from architectus "master builder, chief workman" (see architect). Since that time the word architecture has actualized about 7 components: (1) the art of planning, designing; (2) constructing buildings; (3) the style in which a building is designed and constructed; (4) the architecture of the city's buildings; (5) the science, art, or profession of designing and constructing buildings, bridges (6) the internal organization of a computer's components with particular reference to the way in which data is 
transmitted; (7) the arrangement of the various devices in a complete computer system or network [Collins Dictionary]. This expansion of the lexical semantics of the word architecture is due to its combinability with other units of the sentence and the discourse. We argue that lexical or lexical-grammatical combinability reflects the "local context" of the unit , and the semantic combinabilityof the unit correlates with the notion of the "local context" of the unit and its global conyext in disscourse, the both support the dynamic character of the word lexical meaning [see 8, p. 232; 9]. Traditionally lexical semantics is concerned with the components of the word meaning and their relationships with other words. According to Lyons the componential analysis "in lexical semantics defines the meaning of the word simultaneously in terms of external, interlexical and relational structures or semantic fields" [10, p. 107]. Adopting the lexical decomposition of word meaning into components and then establishing relations between these components can make words in the literary text more revealing of meaning than treating them as independent entities [2, p. 289].

Corpora analysis and comments. We shall consider the compositionality of the lexical meaninig of the unit architecture registered in several encyclopedic dictionaries to prove its typology:

(i) We shall start with the entry in the Cambridge Dictionary and then the Oxford reflecting British English (1) the art or science of building specifically: the art or practice of designing and building structures and especially habitable ones; (2) formation or construction resulting from or as if from a conscious act; (3) a unifying or coherent form or structure; (4) architectural product or work; (5) a method or style of building; (6) the manner in which the components of a computer or computer system are organized and integrate different program architectures.

(ii) Oxford Dictionary: (1) the art or practice of designing and constructing buildings; (2) schools of architecture and design; (3) the style in which a building is designed and constructed, especially with regard to a specific period, place, or culture; (4) the conceptual structure and logical organization of a computer or computer-based system; (5) an orderly arrangement of different programs;

(iii) and we shall go on comparing the British English lexical meaning structure with the entries in two American dictionaries the: American Treasury and Merriam-Webster: (1) the art and science of designing and erecting buildings; (2) buildings and other large structures; (3) a style and method of design; (4) orderly arrangement of parts, structure; (iv) Merriam-Webster: (1) the art or science of building specifically; (2) the art or practice of designing and building structures and especially habitable ones; (3) formation or construction resulting from or as if from a conscious act; (4) a unifying or coherent form or structure; (5) architectural product or work buildings; (6) a method or style of building; (7) the manner in which the components of a computer or computer system are organized and integrate different programs. The comparison of the British and American entries reveals the common semantic structure of the unit with slight differences in the periphery component arrangement. There are three principles of defining the componential analysis - general linguistic, semantic, and lexis classificatory [12, p. 83; see also 4, p. 109]. In this paper we share Leech's definition of the term, componential analysis is "the method of reducing a word's meaning to its ultimate contrastive elements" [7, p. 89].

First, the definitional and then componential analyses resulted in a set of components:

(i) the art and science of designing and erecting buildings, Linguistic semantics studies the compositionality aspect of the word and is more concerned with literal meaning. Linguistic semantics studies the compositionality aspect of the word and is more concerned with literal meaning. Linguistic semantics studies the compositionality aspect of the word and is more concerned with literal meaning;

(ii) education/profession, the various devices in a complete computer system or network;

(iii) erecting/building;

(iv) the style;

(v) urban complex;

(vi) the arrangement of programs.

When millions of linguistic facts are presented as a store of the language in-use its analysis makes the results reliable. The fact is that the corpus does not state the correct or wrong usage, it registers what is there in written and oral form. The analysis of the British National Corpus provided us with the following data: the total sample frequency of the architecture lexeme use is 2953 . We have considered 100 text fragments where 49 from 100 samples share the common component of art (of design, building). The distributional analysis of the lexeme "architecture" (art) as the headword with modifiers in the preposition in the text fragments registered in the $\mathrm{BNC}$, for instance:

(a) the names of streets, cities, countries:

Constitution Street are interesting examples of 19th century architecture.

What is a really important part of London architecture? 
His designs borrow freely from both ancient Egypt and modern architecture's greatest hits.

European Alexandria lingers on in the Italianate architecture, the long lines of balconies along the seafront;

(b) periods in the life of the country:

When you think of sixties architecture what do you think of?

The organisers stress that this is not an exhibition about Ruskin's relationship to Victorian architecture.

With it's regency architecture and it's floral splendor cheltenham has all the looks of an affluent tow;

(c) time periods:

I should go to the design museum. (SP: PS47M) Ancient architecture's beautiful, you should.

I should go to the design museum. Ancient architecture's beautiful, you should.

Second, the British public needs to see exactly what good modern architecture styles:

The lay judges, like Stanhope and Stirling, probably appreciated the shortcomings of neoclassical architecture for modern building, and saw the French style as a suitable nineteenth-century alternative.

Prague was to develop an exciting and original form of late Gothic architecture.

The prepositional modifies as features of the "local context" and the "global" context of the discourse reveal the referred components (a, b, c, d) which can shift the lexeme to various semantic domains.

And 37 samples from 100 share the common component systemic network relating the given units to the systemic organization and it can organize the lexemes around the dominant component of another semantic domain, for instance:

Systems integration and support in compliance with Apple's Vital architecture.

Informix Inc, Ingres and Sybase Inc offer more open relational database architectures.

Here the Macintosh architecture looks after most of the conversion for you.

It introduced Informix-Gateway for Distributed Relational Database Architecture last month.

The component computering in the given context shifted from the periphery position to the dominant one which related the unit to another semantic domain and naturally to a different conceptual domain. The word lexical meaning and its contextual meaning change over time yet often appear to be and are experienced as stable [cf culture and communication: 1, p. 69].

The conceptual analysis reveals knowledge of current societal and linguistic practice which is verbally represented internally and externally [see
11, p. 85]. As for the contextual semantics, Ryle believes that one and the same word can represent different concepts, for instance, the concept designated by the word "architecture" would be quite different [see 14, p. 1-2]. According to the actualized components we can refer the item architecture to various conceptual domains like:

Art (planning, designing, construction):

The classic triad of the visual arts: architecture, painting and sculpture.

Artists working in media other than Vasari's chosen painting, sculpture and architecture.

Education (university level):

She holds a diploma in Landscape Architecture from Manchester Polytechnic.

Project which was run from the Department of Architecture and Building Science at the University of Strathclyde entitled' User Education in the construction.

Profession (one of the oldest):

Architecture is very much like the oldest profession in the world.

In view of Tite's involvement in architecture as a profession, and his later attitude, this was an extraordinary suggestion.

Computering:

Downsizing by replacing their minicomputers with equivalent computing power based on PC architecture.

Enabling Mac applications to run on the Intel architecture would be a major task.

The relationship between language and the world is not straightforward, but the language shapes the human perception which again reflects the world. And due to the componential structure of the word lexical meaning in which one can find common features to understand on the intercultual level [3, p. 122]. Though a language worldview stresses the individual nature of that language we are confident to discover some of common concepts verbalized by various language means [see 15, p. 8].

Findings and perspective. The word lexical meaning is not static but dynamic till it is in-use therefore it undergoes its perpetuum change and expands or curtails the number of components due to its contexts. The lexeme architecture revealing the dominant component of "art" retains its semantic domain representing the conceptual system of architecture and the periphery components like the internal organization of a computer's components with particular reference to the way in which data is transmitted; or the arrangement of the various devices in a complete computer system or network can reveal 
common component systemic organization and refer the units to the semantic domain computer system or network. Accordingly, we can observe the process of disintegrating one domain and organizing a new one due to the development of software which is reflected in language.

\section{References:}

1. Allard-Kropp Manon. Languages and Worldview. Open Educational Resources Collection. 2020. № 17.77 p. URL: https://irl.umsl.edu/oer/17.

2. Belfarhi Khadija. The componential analysis of literary meaning. Colombian Applied Linguistics Journal. 2013. Vol. 15 (2). P. 288-301.

3. Hewitt Peter. Language and Worldviews. A Journal of the Performing Arts. 2016. Vol. 21. P. 122-130.

4. Hobi Enas Abdul Razzaq. Componential Analysis of Meaning. Al-Adab Journal. 2011. Vol. 98. P. 109-122.

5. Kipper Jens. A Two-Dimensionalist Guide to Conceptual Analysis. Lancaster, White Cross Mills, 2013. 308 p.

6. Laurence Stephen, Margolis Eric. Concepts and conceptual analysis. Philosophy and Phenomenological Research. 2003. Vol. 67. № 2. P. 253-282.

7. Leech Geoffrey. Semantics. Harmondsworth : Penguin Ltd, 1983. 386 p.

8. Lewis Karen. Do we need dynamic semantics / Ed. Alexis Burgess, Brett Sherman. Metasemantics : New Essays on the Foundations of Meaning. Oxford : Oxford University Press, 2014. P. 231-258.

9. Lewis Karen. Dynamic Semantics. Phil Papers. Oxford : Oxford Handbooks Online, 2017. DOI: 10.1093/ oxfordhb/9780199935314.013.14.

10. Lyons John. Linguistic semantics. An introduction. Cambridge : CUP, 1995. 396 p.

11. Mykhaylenko V. V. Conceptual analysis: componential analysis. Naukovy Visnyk. Germanska Filologia. Chernivtsi Uriy Fedkovych Natsionalny Universitet. 2014. № 720. P. 77-86.

12. Mykhaylenko V. V., Bakhov I. S. Glossary of applied linguistics for the majors in translation and TEFL methodology : English - Ukrainian. Kyiv : MAUP, 2019. 545 p.

13. Nida Eugene. Semantic components in translation theory / Ed. G. E. Perren, J. L. M. Trim. Applications of Linguistics. Cambridge : CUP, 1971. P. 341-348.

14. Ryle G. Dilemmas. Cambridge, 1954. 129 p.

15. Underhill James. Humboldt, Worldview and Language. Edinburgh : Edinburgh University Press, 2009. 176 p.

\section{МихайлеНко В. В. ПРО ДИНАМІКУ ЛЕКСИЧНОГО ЗНАЧЕННЯ}

У статті досліджено лексичне значення іменника "architecture" («архітектура») та його контекстуального значення, щц дає змогу визначити пересув компонентів у структурі значення, що може слугувати ознакою формування нового семантичного поля та взаємозв'язку семантичних підсистем у кониептуальній системі. Іменник "architecture” актуалізує домінантний компонент "аrt”, пов'язаний із семантичним полем "аrchitecture”. Слово зазвичай вбудовано в різні сполучення в реченні й починає співвідноситися з ними для актуалізаиії своӥх компонентів під впливом лексико-граматичної та лексикосемантичної сполучуваності. Модифікатори головного слова "architecture" можуть актуалізувати його як домінантні, так і периферійні компоненти. Це робить гіпотезу семантичного зсуву в лексичному значенні слова очевидною. Відповідно до динамічної семантики, англійський іменник "architecture" - «мистеитво будівництва, естетичне застосування законів будівництва за допомогою відповідних матеріалів», є розширеним значенням середньофраниузького “architecture” (1560-ті роки) та латинського оригіналу "architeus" - «майстер-будівельник, головний майстер» (див. «архітектор»). 3 того часу іменник "architecture" актуалізував приблизно сім компонентів, як-от: (1) мистеитво планування, проєктування; (2) будівничтво; (3) стиль, у якому проєктується та будується будівля; (4) архітектура міських будівель; (5) наука, мистецтво або професія проєктування та будівнищтва помешкань, мостів; (6) організачія компонентів програм із посиланням на спосіб передачі даних; (7) розтамування різних програм у комп'ютерній системі чи мережі. Таке розширення лексичної семантики слова “аrchitecture” зумовлене його сполучуваністю з іншими складовими частинами речення та дискурсу. Лексичне значення слова виступає статичним явищем поза використанням, динамічним у процесі вживання, де воно зазнає постійні зміни і розширює або скорочує кількість компонентів під впливом свого контексту. Лексема, що виявляє компонент, який домінує, “анt”, зберігає свою приналежсність до семантичного поля, яке становить кониептуальну систему "architecture" А переміщення компонентів на киталт "the internal organization of a computer's components with particular reference to the way in which data is transmitted", "arrangement of the various devices in a complete computer system or network" із периферійних позицій до домінантних приводить до зміни семантичного поля лексеми, отже, ї̈ конщептуальної системи. У результаті ми спостерігаємо проиес дезінтеграиії одного домену на два "architecture (art) " ma "network (computering)."

Ключові слова: семантика лексичний, контекстуальний, динамічний, поле, концепт, пересув, дискурс. 